\title{
Stochastic frontier analysis of catfish (Clarias gariepinus) aquaculture agribusiness for sustainable fisheries development: Evidence from Nigeria
}

\author{
Eguono Aramide IKPOZA®, Felix Odemero ACHOJA®, Oraye Dicta OGISI ${ }^{\circledR}$, Christy ULIONG®
}

Cite this article as:

Ikpoza, E.A., Achoja, F.O., OGISI, O.D., ULIONG, C. (2021). Stochastic frontier analysis of catfish (Clarias gariepinus) aquaculture agribusiness for sustainable fisheries development: Evidence from Nigeria. Aquatic Research, 4(1), 1-9. https://doi.org/10.3153/AR21001

Delta State University, Department of Agricultural Economics and Extension, Abraka, Delta State, Nigeria

\section{ORCID IDs of the author(s):}

E.A.I. $0000-0002-7633-7289$

F.O.A. 0000-0002-9705-4923

O.D.O. 0000-0002-9068-9694

C.U. 0000-0003-4115-368X

Submitted: 22.05 .2020

Revision requested: 21.06 .2020

Last revision received: 07.07 .2020

Accepted: 10.07.2020

Published online: 25.09 .2020

Correspondence:

Felix Odemero ACHOJA

E-mail: achojafelix@gmail.com

\begin{abstract}
Technical efficiency assessment and enhancement is critical to sustainable fisheries development in Nigeria. This study examines stochastic frontier of catfish aquaculture agribusiness for sustainable fisheries development. Purposive sampling technique was employed to select 110 catfish farmers in areas with high density catfish farms. Primary data were collected directly from catfish farmers using structured questionnaire. The analytical tools used were descriptive statistics, net farm income, stochastic frontier production function (SPF) and t-statistics. The result shows that most of the catfish farmers were young people within the productive age of 40-49 years. Catfish farmers had obtained various levels of formal education. Finding shows that feeds cost was the highest variable cost $(72.75 \%)$. Feed had a positive and significant relationship $(\mathrm{P}<0.05)$ with catfish output. Mean technical efficiency is $53.49 \%$. The estimated variance $(\delta 2 \mathrm{~s}=0.2125)$ is statistically significant $(\mathrm{P}<0.05)$, indicating that profit inefficiency is highly significant among catfish farmers. Estimated Gamma $(\gamma)$ value of 0.26 implies that $26 \%$ of the total variation in catfish profit efficiency is due to the joint effect of technical inefficiency factors. The most significant efficiency factors are fish feed and pond size. The age and educational status of farmers are the most important determining factors of inefficiency in catfish production system. Lack of finance was the most serious constraint faced by catfish farmers. The study recommended that catfish farmers should form cooperative unions to facilitate their access to cooperative funding.
\end{abstract}

Keywords: Stochastic frontier analysis, Catfish aquaculture, Technical efficiency, Sustainable fisheries development

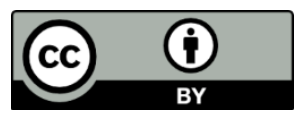

(C) 2021 The Author(s) 


\section{Introduction}

The increasing cases of global undernourishment and starvation among human population, particularly in the developing countries had been reported at various development debate fora. This is a world-wide issue of major concern that calls for scaling up of food production. There aquaculture and fisheries are two of the three important sources (agriculture, aquaculture and fisheries) of food production. As it stands, world's natural stock of fish has finite supply limits. Most of natural water bodies have attained maximum fishing limit. Aquaculture holds the potential for sustainable aggregate fish supply to satisfy fish increasing global fish demand (Okechi, 2004).

Aquaculture refers to the cultivation of aquatic organisms under controlled or semi-controlled conditions for economic and social benefits (Fourier, 2006). Catfish farming is a subset of aquaculture which involves the rearing of catfish under controlled conditions for economic and social benefits. According to Adewunmi and Olaleye (2011), the favoured catfish for culture include Clarias gariepinus, Heterobranchus bidorsalis, Clarias heterobranchus hybrid (heteroclarias), with $C$. gariepinus and $H$. bidorsalis being the most cultured fish in Nigeria. Clarias gariepinus is regarded as an excellent aquaculture species because it grows fast and feeds on a variety of agricultural by-products. It is hardy and can tolerate extreme temperature, easy to produce in captivity with high annual production and good feed conversion rate. Globally, fish provides about 3 billion people with almost 20percent of their intake of animal protein, and 4.3 billion people with about 15 percent of such protein (FAO, 2012). Increasing demand for fish products has resulted in the growth of fish farms to meet a substantial part of the world's food requirement (Olasukanmi, 2012).

The current shortfall in fish supply compared to local demand is putting pressure on the price of fish and its products. This can make fish unaffordable for many households in Nigeria and further decreasing the per capita fish consumption rate (FAO, 2010). However, there is significant interest in sustainable development of the catfish industry in Nigeria. A sure means of substantially solving the demand-supply gap is by embarking on widespread homestead/ small scale fish production. Also, considerable efforts have been directed at examining productive efficiency of fish farmers in Nigeria that is exclusively focused on technical efficiency of fish farmers in general and profitability of fish farming (Kudi et al., 2008). Consequent upon the increment in awareness of catfish farming and a substantial percentage of small scale catfish farmers in Nigeria, it has prompted the interest of researchers in this field. However, most of the past studies in Nigeria focused on large scale fish farming (Obasi, 2002).

The catfish aquaculture sector is yet to record sustainable development in terms of fish output to further close demandsupply gap that is evident in the sector in Nigeria (Olujimi, 2002). Squires et al. (2003) and Achoja et al. (2020), reported that fishers' age and educational attainment have considerable impacts on the technical efficiency fish aquaculture. Young and educated fishers have potential for sustainable development of catfish aquaculture on the basis of their youthfulness and technical skills (Revilla-Molina et al. 2009; Oyinbo et al. 2016; Achoja et al. 2020).

New technologies from research and development initiatives generate sustainable development if they are made available by extension officers to catfish producers for efficient application. As it stands, the relatively high inefficiencies in the catfish aquaculture can be eroded with sustainable fisheries development policies (Baruwa and Omodara, 2019).

There is dearth of empirical information on technical efficiency of catfish aquaculture agribusiness in Nigeria. Catfish business in Nigeria has low and sub-optimal technical efficiency. This low efficiency is attributable to the poor management of some factors of production (Goksel 2008; Onoja and Achike 2011; Oyinbo et al. 2016; Baruwa and Omodara, 2019).

Stochastic frontier analysis of catfish (Clarias gariepinus) aquaculture agribusiness for sustainable fisheries development is a research puzzle that is worthy of investigation. The broad objective of the study is to determine the technical efficiencies of catfish aquaculture using stochastic frontier approach.

The specific objectives are to:

1. Determine the socioeconomic characteristics of catfish producers in the study area;

2. Estimate the cost and return of catfish production;

3. Estimate the technical efficiencies of catfish production;

4. Identify the production constraints faced by catfish aquaculture farmers in the study area.

\section{Material and Methods}

The study was conducted in Delta State, Nigeria. Delta State is located in the Niger delta Zone of Nigeria. It lies between latitude $5^{0} 00^{1}$ and $6^{0} 45^{1}$. The state is located in the Niger Delta Region of Nigeria and lies within mangrove swamp, 
fresh water swamp forest and derived savannah vegetation belts. The state is well irrigated naturally by many rivers, rivulets and streams. It has two prominent seasons, the wet season which, last from March to October and the dry season which last from November to February. The state is shared into three agricultural zones The major occupation of the people is farming and fishing. Their cropping systems are mainly mixed cropping, intercropping as well as sole cropping and the main crops cultivated in the area are cassava, yam, okra, garden egg, cocoyam, rice maize and sweet potato.

Purposive sampling technique was used to sample 110 catfish farmers selected from areas with high density catfish farms. Data were collected from primary sources. Primary data were collected using structured questionnaire which was administered on the respondents. Data collected was on the socioeconomic characteristics such as age, gender, household size, farm size, farming experience, income and level of education and data on catfish production like cost and returns, constraints to catfish production, income and expenditure of the household was also collected. The analytical tools that were employed to achieve the objectives and hypothesis of the study include descriptive statistics, net farm income, stochastic frontier production function analysis, food insecurity line and Z-statistic. Descriptive statistics such as frequency distribution, mean, percentage, minimum and maximum values was also used to achieve objectives I, and vi of the study.

Budgeting technique was used to achieve objective ii. The indicators that were used include Net Farm Income (NFI) and profitability index. NFI is expressed as:

$\mathrm{NFI}=\Sigma P_{Y i} Y i-\Sigma P_{X j}-\Sigma F_{K}$

Where:

NFI= Net Farm Income (\$)/production cycle;

$\mathrm{P}_{\mathrm{Yi}}=$ Unit price of the output of Catfish (\$)

$\mathrm{Yi}=$ Total output of catfish $(\mathrm{Kg})$;

$P x j=$ Unit price of variable inputs $(\$)$

$\mathrm{Xj}=$ Quantity of variable inputs (where $\mathrm{j}=1,2,3, \ldots, \mathrm{n}$ )

$\mathrm{F}_{\mathrm{k}}=$ Depreciated Cost of fixed inputs $(\$)$ (where $\left.\mathrm{k}=1,2,3, \ldots, \mathrm{n}\right)$

$\boldsymbol{\Sigma}=$ Summation sign

The stochastic frontier function used by Onu et al. (2000) as derived from the error model of Aigner et al. (1977) was employed to achieve objectives iii and iv. The Cobb-Douglas production function was fitted to the frontier model of catfish production. The result was estimated using the maximum likelihood method. The stochastic frontier production function is written as:
$Y i=f(X: \beta)+e$

$\mathrm{e}_{\mathrm{i}}=\mathrm{Vi}-\mathrm{Ui}$

Where $\mathrm{Yi}=$ Output of the ith farm

$\mathrm{Xi}=$ Vector of inputs used by the ith farm

$\mathrm{B}=$ Vector of the parameters estimated

ei=Composite error term

$\mathrm{Vi}=$ Random error outside farmers control

$\mathrm{Ui}=$ technical inefficiency effects

The empirical Stochastic frontier model that will be employed is specified as follows:

$\ln \mathrm{Y}_{1}=\beta 0+\beta_{1} \ln \mathrm{X}_{1} \mathrm{i}+\beta_{2} \ln \mathrm{X}_{2} \mathrm{i}+\beta_{3} \ln \mathrm{X}_{3} \mathrm{i}+\beta_{4} \ln \mathrm{X}_{4} \mathrm{i}+\beta_{5} \ln \mathrm{X}_{5} \mathrm{i}$ $+\beta_{6} \ln \mathrm{X}_{6} \mathrm{i}+\mathrm{Vi}-\mathrm{Ui}$.

Subscripts ij refer to the jth observation of ith farmer

$\ln =$ Logarithm to base $\mathrm{e}$

$\mathrm{Y}=$ Output of catfish $(\mathrm{kg})$

$\beta_{0}=$ Constant

$\beta_{1}-\beta_{6}=$ Parameters estimated

$\mathrm{X}_{1}=$ Number of Fingerlings

$\mathrm{X}_{2}=$ Fish feed $(\mathrm{kg})$

$\mathrm{X}_{3}=$ Labour (Man-days)

$\mathrm{X}_{4}=\operatorname{Drugs}(\$)$

$\mathrm{X}_{5}=$ Fuel (Litres)

$\mathrm{X}_{6}=$ Pond size $\left(\mathrm{m}^{2}\right)$

$\mathrm{V}_{\mathrm{i}}=$ Random noise (white noise)

$\mathrm{U}_{\mathrm{i}}=$ Inefficiency effects which are non-negative with half normal distribution.

It is assumed that inefficiency effects are independently distributed and $U_{\mathrm{ij}}$ arises by truncation (at zero) of the normal distribution with mean $\mathrm{U}_{\mathrm{ij}}$ and variance $\delta \mathrm{U}^{2}$

Where $U_{i}$ is specified as:

$\mathrm{U}_{\mathrm{i}}=\delta_{0}+\delta_{1} \ln Z 1 \mathrm{i}+\delta_{2} \ln Z_{2 \mathrm{i}}+\delta_{3} \ln \mathrm{Z}_{3 \mathrm{i}}+\delta_{4} \ln \mathrm{Z}_{4 \mathrm{i}}+\delta_{5} \ln \mathrm{Z}_{5 \mathrm{i}}+\delta 6 \ln \mathrm{Z}_{6 \mathrm{i}}$

Where:

$\mathrm{U}_{\mathrm{i}}=$ Inefficiency effect of catfish production

$\delta_{0}=$ Constant

$\delta_{1}-\delta_{6}=$ Parameters to be estimated

$\mathrm{Z}_{1}=$ Farmers age (years)

$Z_{2}=$ Household size of farmer (number)

$Z_{3}=$ Years of Formal education of the farmer (years)

$Z_{4}=$ Years of farming experience of the farmer in catfish production (years)

$Z_{5}=$ Number of years in cooperative society (years) 
$\mathrm{Z}_{6}=$ Number of contacts with extension agents (measured as number of contacts in a year)

\section{Results and Discussion}

This section deals with the results and discussion of findings under the following sub-headings: Distribution of Socioeconomic Characteristics of Catfish Farmers, Cost and Return of Catfish Production, Technical Efficiencies of Catfish Production (technical efficiency factors and technical inefficiency factors), Production Constraints of Catfish farmers.

Table 1. Distribution of demographic parameters of Catfish Farmers

\begin{tabular}{lll}
\hline Parameter & Frequency/\% & Mode \\
\hline Age(years) & $7(8.75)$ & 43 \\
$20-29$ & $16(20)$ & \\
$30-39$ & $30(37.5)$ & \\
$40-49$ & $17(21.25)$ & \\
$50-59$ & $10(12.5)$ & \\
$>60$ & & \\
Gender & $55(68.75)$ & 55 \\
Male & $25(31.25)$ & \\
Female & & \\
Marital Status & $56(70.00)$ & 56 \\
Married & $24(30.00)$ & \\
Unmarried & & \\
Educational Level & $0(0.00)$ & 61 \\
No formal education & $6(7.50)$ & \\
Primary & $13(16.25)$ & \\
Secondary & $61(76.25)$ & \\
Tertiary & & \\
Farming Experience & $49(61.25)$ & $1-5$ years \\
1 -5 years & $22(27.50)$ & \\
6 -10 years & $7(8.75)$ & \\
11 -15 years & $2(2.50)$ & \\
Above 16 years & & \\
Membership of cooperative & $52(65.00)$ & 52 \\
Non member & $28(35.00)$ & \\
Member & & \\
Extension Contact & $50(62.5)$ & 50 \\
No & $30(37.5)$ & \\
Yes & & \\
\hline
\end{tabular}

\section{Socioeconomic Characteristics of Catfish Farmers}

Age

The frequency distribution of respondents according to socio economic characteristics is shown in Table 1. The table shows that majority (37.5\%) of the catfish farmers fell within the productive age range of 40-49years. The average age of the catfish farmers was estimated to be 43 years which means that catfish farmers are in their prime and active age of production. They are likely to be productive in the next decade and catfish production in the country will likely increase. According to Sikiru, et al. (2009), this age bracket is a productive age which predicts better future for catfish production.

\section{Gender}

Table 1 showed that both men and women were actively involved in catfish production but the percentage of men were more. Men accounted for $68.5 \%$ while female were about $31.25 \%$. The high number of males might be attributed to hard task carried out in catfish production process.

\section{Marital status}

Result from Table 1 showed that about $70 \%$ of the respondents were married. About $13.75 \%$ were single while $7.5 \%$ were divorced and $8.75 \%$ were widowed. The high number of married people in the business was to reduce labour cost as most married persons have children that constitute the labour force in catfish production.

\section{Farming experience}

Table 1 also shows the distribution of respondents by farming experience. As shown in the table there was influx of new entrants into catfish production in recent times. This could be due to the ban on importation of frozen catfish product by the federal government. This is represented by about $61.25 \%$ who had from 1-5 years of experience as the majority. This was followed by about $27.5 \%$ who had farming experience of $6-10$ years, $8.75 \%$ had farming experience of $11-15$ years and $2.5 \%$ had farming experience of 6-10 years, $8.75 \%$ had farming experience of $11-15$ years and $2.5 \%$ had farming experience of $11-15 y e a r s$ and $2.5 \%$ had farming experience of $6-10$ years, $8.75 \%$ had farming experience of $11-15$ years and $2.5 \%$ had farming experience of 16 years and above. Table 1 shows that the average farming experience of the respondents was about 5 years which means that they were still new in the business and had no experience in catfish production. This agrees with Williams et al (2012), that the ability to manage fish pond efficiently depends on the years of experience and this is directly related to the total productivity of the farm.

\section{Educational level}

The result shows that $7.5 \%$ of small scale catfish farmers had six years of formal education and $26.3 \%$ of small scale catfish farmers had 12 years of formal education while $40 \%$ of small scale catfish farmers had 10 years of formal education. With this level of education, there is tendency of the farmers being able to increase the level of technology adopted and skill acquisition. This study agrees with the findings of Ologbon 
(2012) that found out that greater percentage of small scale catfish farmers in Ogun State had formal Education.

\section{Membership of cooperative society}

The result in Table 1 shows that $65 \%$ of the catfish farmers in the study area belong to a cooperative society while $35 \%$ of the respondents do not belong to any cooperative society.

\section{Extension contact}

The information in Table 1 reveals that majority of the farmers $(62.5 \%)$ have access to extension service delivery while $37.5 \%$ of the catfish farmers in the study area indicated that they do not have contact with extension agents.

\section{Cost and Return of Catfish Production}

The information in table 2 shows the cost and return of catfish production in the study area. The average fixed cost incurred by the farmers in the study area amounted to the sum of $\$ 444.44$. Findings indicated that cost of feed accounted for about $\$ 1,584.31$ which is the greatest variable cost. This is followed by purchase of fingerlings and labour that accounted for $\$ 289.36$ and $\$ 78.55$ respectively. From the enterprise budget analysis for the catfish shown in the table, it could be observed that catfish production is a profitable venture in the study area. The result of the survey shows a Gross Margin of 92.32percent and average net returns was calculated to be $\$ 1,411.9$. The result also revealed that rate of return was
0.575 . Since the rate of return is greater than one, catfish production is considered profitable in the study area. The business is profitable with about $57.5 \%$ profit on investment. The study revealed that for every $\$ 1.00$ invested in catfish production, a return of $\$ 0.57$ is made. This result is consistent with the finding of Alawode (2014) who observed that fish farming is profitable. Therefore, the null hypothesis which states that catfish farming is not profitable is rejected and the alternative accepted.

Table 2. Cost and Return of catfish production

\begin{tabular}{ll}
\hline Items & Amount( $)$ \\
\hline Variable cost & \\
Feeds & 570350 \\
Fingerlings & 104169 \\
Medication & 10300 \\
Labour & 28277 \\
Water & 10804 \\
Total variable cost & $\mathbf{7 2 3 ~ 9 0 0}$ \\
Fixed cost & \\
Pond preparation & 108000 \\
Water pump & 52000 \\
Total fixed cost & $\mathbf{1 6 0 0 0 0}$ \\
Total cost & $\mathbf{8 8 3 9 0 0}$ \\
Total Revenue & $\mathbf{1 3 9 2 ~ 2 1 7}$ \\
Gross margin & $\mathbf{9 2 . 3 2 \%}$ \\
Net farm income & $\mathbf{5 0 8 ~ 3 1 7}$ \\
Return on Investment & $\mathbf{0 . 5 7 5}$ \\
\hline
\end{tabular}

\section{Technical Efficiency Level of Catfish Production System}

Table3. Profit Efficiency and inefficiency factors of catfish production

\begin{tabular}{lllll}
\hline Variables & Parameters & Coefficients & Standard error & t-value \\
\hline Profit factors & & & & \\
Constant & $\mathrm{X}_{0}$ & 0.2116 & 0.1169 & 1.810 \\
Fingerlings & $\mathrm{X}_{1}$ & -0.9731 & 0.9782 & -0.9948 \\
Fish feed & $\mathrm{X}_{2}$ & 0.7128 & 0.2192 & $3.252^{* * *}$ \\
Labour & $\mathrm{X}_{3}$ & -0.1581 & 0.1457 & -1.085 \\
Pond Size $\left(\mathrm{m}^{2}\right)$ & $\mathrm{X}_{4}$ & 0.6071 & 0.1193 & $5.089^{* * *}$ \\
Inefficiency Factors & & & & \\
Constant & $\mathrm{Z}_{0}$ & 0.7017 & 0.1169 & $6.002^{* * *}$ \\
Age & $\mathrm{Z}_{1}$ & 0.9397 & 0.1877 & $5.006^{* * *}$ \\
Household size & $\mathrm{Z}_{2}$ & 0.1434 & 0.0706 & $2.031^{* *}$ \\
Years of Education & $\mathrm{Z}_{3}$ & -0.2184 & 0.0526 & $-3.951^{* * *}$ \\
Farming experience & $\mathrm{Z}_{4}$ & -0.2068 & 0.1648 & -1.255 \\
Number of extension contacts & $\mathrm{Z}_{5}$ & -0.3251 & 0.1395 & $-2.330^{* *}$ \\
Diagnostics statistics & & & & \\
Total variance & $\delta^{2}$ & 0.2125 & 0.0328 & $6.478^{* * *}$ \\
Variance ratio & $\Gamma$ & 0.2574 & 0.1409 & 1.827 \\
LR Test & & 0.1727 & & \\
Log-likelihood function & & 0.4053 & & \\
\hline
\end{tabular}




\section{Estimated Profit Factors}

The result of maximum likelihood (ML) estimates of the Cobb-Douglas stochastic frontier production function for small scale catfish farmers are presented in Table 3.

\section{Fingerlings}

The coefficient of cost of fingerlings is the a priori expected negative sign. This implies that $1 \%$ increase in the cost and quantity of fingerlings stocked beyond a threshold level will reduce the quantity of catfish output and technical efficiency of resource utilization as well as profit by 0.9731 .

\section{Fish feed}

Feed has the a priori expected positive sign and significant $(p<0.05)$ showing a direct relationship with output and profit efficiency. This implies that a $1 \%$ increase in of feed will increase the quantity of catfish output by 0.7128 .

\section{Pond size}

Pond Size has the a priori expected positive sign and significant $(\mathrm{p}<0.05)$ showing a direct and positive relationship with output and profit efficiency. This implies that a $1 \%$ increase in of feed will increase the quantity of catfish output by 0.6071 .

\section{Technical Inefficiency Factors}

Table 3 shows the result of technical inefficiency factors in catfish production system. The estimated variance $\delta^{2}=$ 0.2125 is statistically significant at $1 \%$ level of probability. This value indicates that profit inefficiency is highly significant in the catfish farmers' production activities. The $\gamma$ parameter shows the relative magnitude of the variance in output associated with technical efficiency. The coefficients of the variables derived from the Maximum Likelihood Estimation (MLE) are very important for discussing results of the analysis of the data. This coefficient represents percentage change in the dependent variables due to percentage change in the independent (or explanatory) variables. The value of estimated Gamma $(\gamma)$ is 0.2574 and is statistically significant at $(p<0.05)$ indicating that $26 \%$ of the total variation in catfish profitability is due to technical inefficiency factors.

\section{Age}

Age of catfish farmers entered the technical inefficiency model with a negative sign (-0.9397) and significant $(p<0.05)$. This finding implies that increase in age (old age) of catfish farmers will increase the technical inefficiency of catfish production system in the study area. This result collaborates with the earlier report of Achoja et al. (2020) that age is an important variable in the productivity of aquaculture in Nigeria.

\section{Household size}

The result shows that house size has a positive and significant relationship $(p<0.05)$ with the technical inefficiency of catfish production system. This finding implies that a $1 \%$ increase in household size will increase technical inefficiency of catfish farms by 0.1434 . A catfish farmer with large household will likely divert resources meant for the fish farm to family upkeep to the detriment of the farm.

\section{Years of education}

This variable entered the technical inefficiency model with a negative coefficient $(-0.2184)$ and significant $(p<0.05)$. This finding indicates that increase in the years of education, especially with catfish orientation will reduce the technical inefficiency of catfish production system. This result implies that an educated catfish farmer will be able to adopt modern fish farming technologies and avoid wastage of farm resources, thereby reducing technical inefficiency. This result collaborates with the earlier report of Achoja et al. (2020) that education is an important human capital variable in the productivity of aquaculture in Nigeria.

\section{Number of extension contacts}

The frequency of extension contact with catfish farmer entered the technical inefficiency function with a negative coefficient $(-0.3251)$ and it is significant $(p<0.05)$. This implies that the more the number of extension contact a catfish farmer has with extension officers the lower the technical inefficiency in the catfish production system. More access to extension information on catfish production the lower the resulting technical inefficiency.

\section{Technical Efficiency of Catfish Farms}

Table 4. Analysis of Technical Efficiency of Catfish Farms

\begin{tabular}{lll}
\hline Technical Efficiency level (\%) & Frequency & Percentage \\
\hline$<41$ & 14 & 17.5 \\
$41-50$ & 18 & 22.5 \\
$51-60$ & 35 & 43.75 \\
$61-70$ & 12 & 15 \\
$71-80$ & 1 & 1.25 \\
$81-90$ & 0 & 0 \\
$91-100$ & 0 & 0 \\
Total & 240 & 100 \\
\hline Mean Technical efficiency & $53.49 \%$ & \\
Minimum Technical & $46.01 \%$ & \\
efficiency & & \\
Maximum Technical efficiency & $71.21 \%$ & \\
\hline
\end{tabular}


The Technical Efficiency shows the ability of farmers to derive maximum output from the inputs used in catfish production. Given the results of the Cobb-Douglas stochastic frontier model, the technical estimates are presented and discussed in Table 3. The Technical efficiency of the sampled households is less than 1 indicating that all the households are producing below the maximum efficiency frontier. A range of technical efficiency is observed across the sampled households where the spread is large. The best catfish household had a Technical Efficiency of $71.21 \%$, while the worst household had a technical efficiency of $46.01 \%$. The mean Technical efficiency was $53.49 \%$. This implies that on the average, the respondents were able to attain approximately $53.5 \%$ of optimal technical efficiency from a given set of inputs utilization in catfish production system. This shows that catfish farmers households Technical Efficiency can be improved by $46.51 \%$ in order to raise the level of catfish technical efficiency in the study area. The finding tallies with the result obtained by Tsue et al. (2012) in their study on profit efficiency among catfish farmers in Benue State, Nigeria. Their findings showed that profit efficiency ranged from 23 percent to 99 percent with a mean efficiency of 84 percent.

\section{Production Constraints Faced by Catfish Farmers}

Some constraints were identified as hindrances to technical efficiency of catfish production system in the study area. These constraints include: lack of finance, acquisition of Land, purchase of farming inputs, technical support from government or local authorities, pollution and environmen-tal/climate change. Among the various constraints that affect the level of productivity in the study area, lack of finance was identified as the most serious challenge, followed by tech-nical support from government / local authorities. The result of this finding supports that of Tisdell (2003) who stated that the most important factor inhibiting fish farmer's productiv-ity in the study area include lack of access to financial capital and high cost of feed or other farm input.

Table 5. Production Constraints Faced by Catfish Producers

\begin{tabular}{llllll}
\hline Name & $\begin{array}{l}\text { Not a } \\
\text { prob- } \\
\text { lem }\end{array}$ & $\begin{array}{l}\text { Minor } \\
\text { problem }\end{array}$ & $\begin{array}{l}\text { Major } \\
\text { Problem }\end{array}$ & Mean & Remarks \\
\hline Lack of finance & 7 & 26 & 47 & 2.50 & Significant \\
$\begin{array}{l}\text { Acquiring land on which to farm } \\
\text { Farming inputs(water, fingerlings, }\end{array}$ & 7 & 43 & 30 & 2.29 & Significant \\
$\begin{array}{l}\text { equipment and machinery) } \\
\text { Technical support from government/lo- }\end{array}$ & 5 & 59 & 16 & 2.14 & Significant \\
$\begin{array}{l}\text { cal authorities } \\
\text { Pollution }\end{array}$ & 44 & 31 & 2.33 & significant \\
Environmental/Climate Change & & 37 & 19 & 1.94 & Not significant \\
\hline
\end{tabular}

Cut off point $=2.00$

Mean $>2.00=$ a problem, mean $<2.00=$ not a problem 


\section{Conclusion}

This study examines stochastic frontier of catfish aquaculture agribusiness for sustainable fisheries development in Nigeria. It was found out that catfish farming in the study area is relatively young and there is hope for an increase in level of involvement among the people in the study area. The majority of those who were involved in catfish production were able bodied men in their active age bracket, hence the potential to sustain catfish farming for many more years. A positive net farm income with increased return per naira invested indicated that catfish farming in the study area was profitable. Quantity of fingerlings and fish feed negatively and positively influencing the output of catfish respectively. The result shows that the modal class of the catfish farmers was within the productive age of 40-49 years. Catfish farmers had obtained various levels of formal education. Finding shows that feeds cost was the highest variable cost. The result also revealed that the rate of return on investment was $57.5 \%$. The study revealed that for every $\$ 1.00$ invested in catfish production, a net return of $\$ 0.57$ is generated. Feed has a positive and significant relationship with catfish output. Mean technical efficiency is $53.49 \%$. The profit inefficiency is highly significant among catfish farmers. About $26 \%$ of the total variation in catfish profitability is due to technical inefficiency factors. The most significant efficiency factors are fish feed and pond size. Age of farmer, educational attainment, lack of finance and technical support from government authorities are the most important inefficiency factors that require urgent policy attention for sustainable catfish aquaculture development.

Based on the findings of the study, the following recommendations are hereby made to promote increased catfish production in the study area.

Government should provide facilities such as incentives, subsidies and facilitate access to credit by catfish farmers in the study area by the review of the stringent lending policies of the formal lending institutions. Catfish farmers should come together to form co-operative unions to facilitate their access to credit and other inputs. Adequate trainings and seminars should be held at interval to update catfish farmers' knowledge on the art of catfish farming so that they could have access to improved methods and technologies of catfish production. Effort should be made to bring down the cost of feeds by exploring alternative sources of feed for catfish through well-funded research.

\section{Compliance with Ethical Standard}

Conflict of interests: The authors declare that for this article they have no actual, potential or perceived conflict of interests.

Ethics committee approval: The research was carried out with approval of the Ethical Committee of the Department of Agricultural Economics and Extension, Delta state university, Asaba campus, Nigeria (06/07/2019). We (the authors) hereby declare that this research does not include any experiments with human or animal subjects

Funding disclosure: No funding was received from external bodies, institutions or agencies for the execution of this research.

Acknowledgments: We (the authors) hereby acknowledge all the authors whose works were reviewed while conducting this study. We also appreciate our professional colleagues whose criticisms and contributions have added value to this article.

\section{Disclosure: -}

\section{References}

Achoja, F.O., Gbigbi, T.M., Ikpoza, E.A., Denghan, J.E. (2020). The strategic participation of young people in shrimp farming value chain in Nigeria. Yüzüncü Yıl Üniversitesi Tartm Bilimleri Dergisi, 30(1), 197-203. https://doi.org/10.29133/yyutbd.661848

Adewunmi A. A. and V.F. Olaleye (2011). Catfish culture in Nigeria: Progress, prospects and problems", African Journal of Agricultural Research, 6(6), 1281-1285.

Aigner D.J., C.A.K. Lovel and P. Schmidt, (1977). Formulation and estimation of stochastic frontier production function models. Journal of Econometrics, 6(1), 21-37. https://doi.org/10.1016/0304-4076(77)90052-5

Alawode O.O. and Jinad A.O. (2014). evaluation of technical efficiency of catfish production in Oyo State: A case study of Ibadan Metropolis. Journal of Emerging Trends in Educational Research and Policy Studies, 5(2), 223-231.

Baruwa O.I, Omodara O.D (2019). Technical efficiency of aquaculture system in Oyo State, Nigeria: Stochastic frontier approach. Journal of Aquatic Research \& Marine Sciences, 114-120.

https://doi.org/10.29199/ARMS.201026

FAO (2010). The State of World Fisheries and Aquaculture, Rome, pp.88, http://www.fao.org/3/a-i1820e.pdf, ISBN: 97892-5-106675-1 
FAO (2012). The State of World Fisheries and Aquaculture, Rome, pp. 209, http://www.fao.org/3/a-i2727e.pdf, ISBN: 978-92-5-107225-7.

Fourie, J.J. (2006). “A Practical Investigation into Catfish (Clarias gariepinus) Farming in the Vaalharts Irrigation Scheme", Department of zoology and Entomology, University of the Free State, Faculty of Natural and Agricultural Sciences.

Goksel A. (2008). Determining the factors affecting efficiency scores in agriculture. International Journal of Agricultural Science, 3, 328-330.

https://doi.org/10.3923/ijar.2008.325.330

Kudi T.M., Baka F.P., Atala T.K. (2008). Economics of fish production in Kaduna State Nigeria. ARPN Journal of Agriculture and Biological Sciences, 5(5\&6), 17-21.

Obasi, P.C. (2000). The Determinants of Food Consumption and Agricultural Productivity in Imo State Nigeria. Ph.D Thesis, Federal University of Technology, Owerri, Nigeria.

Okechi, J.K. (2004). Profitability Assessment A Case Study of Africa Catfish (Clarias gariepinus) Farming in the Lake Victoria Basin, Kenya United Nations University Fisheries Training Programme.

Olasukanmi, J.B. (2012). Economic Analysis of Fish Farming in Osun State, South Western Nigeria, Proceedings of the International Institute of Fisheries Economics and Trade Tanzania, pp. 1-10.

Olujimi O.J. (2002). Economic Efficiency in the coastal small scale fisheries in Lagos state, Nigeria, Federal College of Fisheries and Marine Technology, Victoria Island, pp. 16.

Ologbon A.C., Ambali I. (2012). Poultry enterprise combination among small-scale farmers in Ogun State, Nigeria: A technical efficiency approach. Journal of Agriculture and Veterinary Sciences, 4(1), 7-15.
Onoja A.O., Achike A.I. (2011). Resource productivity in small-scale catfish (Claria gariepinus) farming in River state Nigeria: A translog model approach. Journal of Agricultural and Social Research, 11(2), 139 -146.

Onu J.K., Amaze P.S., Okunmadewa F.Y., (2000). Determinants of cotton production and economic efficiency, African Journal of Business and Economic Resources, 1, 234240.

Oyinbo O., Mohammed O.M., Falola A., Saleh M.K. (2016). Technical efficiency of catfish farming in Alimosho local government area of Lagos State, Nigeria: A gender perspective, Agricultura Tropica et Subtropica, 49, 45-49. https://doi.org/10.1515/ats-2016-0006

Revilla-Molina I.M., Bastiaans L., van Keulen H., Mew T.W., Zhu Y.Y. (2009). Improvement of technical efficiency in rice farming through interplanting: A stochastic frontier analysis in Yunnan, China. DEGIT Conference Papers, DEGIT, Dynamics, Economic Growth, and International Trade.

Sikiru B.O., Omobolanle N.M, Ayorinde B.J.O., Adegoke O.O. (2009). Improving clarias productivity. Journal of Biological Resources, 3(1-2), 24-28.

Squires D., Grafton Q., Alam F., Omar H.I. (2003). Technical efficiency in the Malaysian gillnet artisanal fisheries. Environmental Development Economics, 8, 481-504. https://doi.org/10.1017/S1355770X0300263

Tisdell, C. (2003). Economics and marketing in aquaculture farming. Aquatic Animals and Plants. Blackwell Publishing Ltd, Oxford. ISBN 0-85238-22-7. Pp237-251

Tsue, P.T., Lawal W.L., Ayuba, V.O. (2012). Profit Efficiency among catfish farmers in Benue State, Nigeria. African Journal of Food, Agriculture, Nutrition and Development, 12(6), 6759-6775.

Williams S.B., Kareem R.O., Ojolowo O.A. (2012). Economic analysis of catfish production in Ile-Ife, Osun State, Nigeria. Journal of Human Ecology, 40(1), 1-7. https://doi.org/10.1080/09709274.2012.11906518 